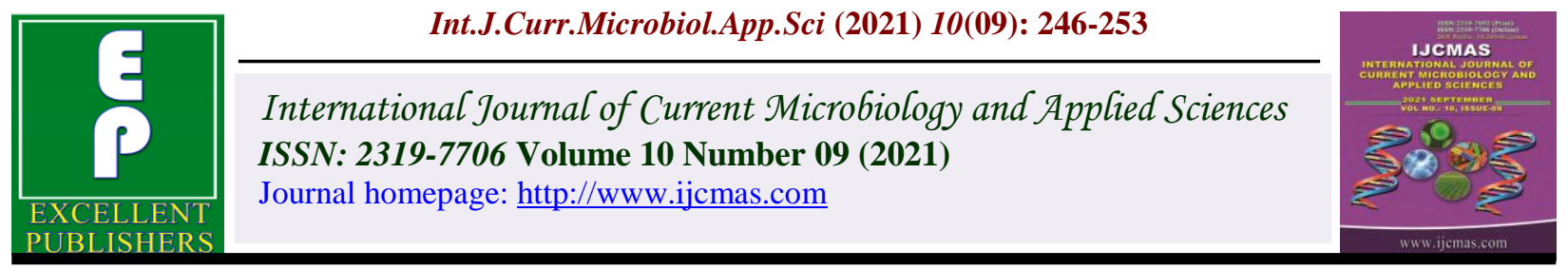

Original Research Article https://doi.org/10.20546/ijcmas.2021.1009.028

\title{
Combining Ability in Pearl Millet for Yield and Yield Attributing Characters
}

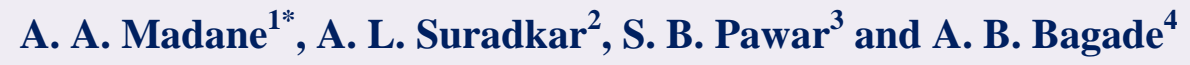 \\ ${ }^{1}$ Department of Genetics and Plant Breeding, \\ ${ }^{2}$ Department of Entomology, College of Agriculture, Badnapur, M.S., India \\ ${ }^{3}$ Department of Research, ${ }^{4}$ Department of Breeding, National Agriculture Research Project, \\ Aurangabad, M.S., India \\ *Corresponding author
}

\section{A B S T R A C T}

Keywords

Combining

ability,

Crosses,

Line,

Testers

Article Info

Accepted:

15 August 2021

Available Online:

10 September 2021
The experimental material comprised of thirty two crosses along with twelve parents (four lines and eight testers) and standard checks AHB 1200 Fe and AHB 1269. The experiment was laid out in Randomized Block Design with two replications. The observations were recorded on ten characters viz., days to 50 per cent flowering, days to maturity, plant height, number of effective tillers, earhead length, earhead head girth, downey mildew, 1000 grain weight, grain yield and fodder yield. The estimates of GCA effects revealed that most of the hybrids exhibiting higher grain yield than the standard hybrid check AHB $1200 \mathrm{Fe}$ and AHB 1269 were based on two females viz., ICMA 91444 and ICMA 00888, and involved based on males viz., AUBI 15308 and AUBI 15615. The studies on specific combining ability (SCA) effects, it was observed ICMA 91444 $\mathrm{x}$ AUBI 15157 was observed the best specific combination for the trait grain yield.

\section{Introduction}

Pearl millet or bajra (Pennisetum glaucum (L.) $\mathrm{R} . \mathrm{Br}$.) is the world's sixth and India's fourth most important cereal food crop after rice, wheat and maize. It is commonly known as pearl millet, cat tail, spiked or bulrush millet, cumbu and locally known as bajra or bajari in different parts of the world. It belongs to the family Poaceae (Gramineae), subfamily Panicoideae having chromosome number 2n=14, genus Pennisetum and species glaucum and also others. Pearl millet or bajra is a highly cross- pollinated crop with 
protogynous (pistil mature before stamens) flowering and wind-borne pollination mechanism, which fulfils one of the essential biological requirements for a hybrid development programme.

Pearl millet has a balanced genetic load and suffers from significant inbreeding depression (Harinarayana, 1980). As a result, the varieties sought for development in pearl millet should be heterozygous to be heterotic and homozygous to be synchronous and evenly productive. As a result, breeding efforts are focused on creating hybrids, synthetic, and composite populations. The quantum leap in pearl millet productivity (from $303 \mathrm{~kg}$ to 850 $\mathrm{kg} / \mathrm{ha}$ ) was made possible primarily through the production of hybrids using the cytoplasmic genetic male sterility system. Burton (1958) was the first to discover the Tift 23A cytoplasmic male sterile line, which was developed in Tifton, Georgia, USA. This prepared the path for hybrid seed development in Pearl millet. The first Pearl millet hybrid, HB-1, was released in India in 1965 (Athwal, 1965), and several promising hybrids have since been created and released for general cultivation, including HB-1, HB-2, HB-3, HB4 , and HB-5. The use of other sources of male sterility was then thought necessary, and study in this area resulted in the identification of multiple alternative sources such as A1, A2, A3, A4, A5, and so on. The present study was, therefore, conducted to estimate nature and magnitude of heterosis for yield and its components.

\section{Materials and Methods}

The parental materials consisting of 4 male sterile lines used as female, 8 inbreds or tester used as male and 2 checks were used and obtained from National Agricultural Research Project (NARP), Aurangabad. The crosses were done in line $\mathrm{x}$ tester fashion during Kharif 2020.
The following important parents are used in the crossing programme and cross produced for the studies in pearl millet.

\section{Parents}

Female (A line)

ICMA 98222

ICMA 91444

ICMA 06777

ICMA 00888

Male (R line)

AUBI 15615

AUBI 15003

AUBI 15026

AUBI 15051

AUBI 15157

AUBI 15236

AUBI 15039

AUBI 15308

\section{Checks}

AHB $1200 \mathrm{Fe}$

AHB 1269

The crossing programme for obtaining crossed or hybrid seed was undertaken during Kharif 2020 at the field of National Agricultural Research Project (NARP), Aurangabad. 4 male sterile lines (female) and 8 inbreds 
(male) were crossed in line $\mathrm{x}$ tester fashion (4 x $8=32$ ). These crossed seed obtained were utilized as F1 or hybrid seed in the present research or investigation. The experiment was laid out in a Randomized Block Design (RBD) with 2 replications. The total number of treatments was 46 , comprising of $32 \mathrm{~F} 1$ 's, 4 females and 8 male parents with 2 checks.

The parent and hybrids were planted in a plot of 1 row of $4.0 \mathrm{~m}$ length having a row to row spacing $45 \mathrm{~cm}$ and $15 \mathrm{~cm}$ plant to plant.

In order to ascertain or study the combining ability, parents were also included in the same set and analysis of the data was done.

In the form of modified line $\mathrm{x}$ tester design as suggested by Arunachalam (1974). Mean data were used for statistical analysis. In order to test the combining ability effects of parents (gca), crosses (sca) and to understand the nature of gene action, the combining ability variances were worked out by following line $\mathrm{x}$ tester analysis as suggested by the Kempthorne (1957).

\section{Results and Discussion}

\section{General combining ability $(G C A)$ effects}

The GCA effects varied significantly for different characters and different parents. The data on GCA presented in Table 2 indicated that none of the female or male parents possessed good general combining ability uniformly for all the characters. The parents showing good general combining ability for three or more character have been presented.

The female parents ICMA 98222 showed significant $G C A$ effects in desirable direction for days to 50 per cent flowering, days to maturity. Among the females ICMA 06777 exhibited significant GCA effect in desirable direction for plant height, earhead girth and effective tillers. Among males, the combining ability of the male parents AUBI 15308, AUBI 15236 was good for three characters.

The male parent AUBI 15236, exhibited good general combining ability for three important attributes. The remaining parents exhibited good $G C A$ effects for one or two different characters.

For the character days to 50 per cent flowering and days to maturity, the parent's viz., female ICMA 00888 and ICMA 06777, and male AUBI 15003, AUBI 15236 and AUBI 15039 expressed significant negative GCA effect, hence it can be considered as good general combiner. Similar type of report were noted by Shelke and Chavan (2007) and Mainassara (2012).

For the character number of effective tillers per plant, the parent's viz., ICMA 06777, ICMA 00888, AUBI 15051, AUBI 15157 and AUBI 15236 expressed significant positive GCA effect, hence it can be considered good general combiner. Previously reported by Mangra et al., (2015) significant positive GCA effect for number of effective tillers per plant.

For the earhead length, the parent, AUBI 15051 observed significant positive GCA effect. Similar reported by Shelke and Chavan (2007) and Mangra et al., (2015) for earhead length.

In case of character the earhead girth, parents ICMA 06777, AUBI 15003 and AUBI 15026 showed significant positive GCA effect, hence consider as good general combiner. Similar finding were reported by Karad and Harer (2005) and Shelke and Chavan (2007).

In case of the character 1000 grain weight the parents, ICMA 06777, AUBI 15308 and AUBI 15003 exhibited significant positive GCA effect, hence it can be considered as 
good general combiner for 1000 grain weight. Previously similar result have been also reported by Mangra et al., (2015).

For grain yield per plant, the parents ICMA 98222, AUBI 15026 and AUBI 15039 exhibited significant positive GCA effect, hence it can be considered as good general combiner. Previously similar result have been also reported by Karad and Harer (2005), Shelke and Chavan (2007), Mainassara et al., (2012) and Mangra et al., (2015).

The parent's viz., ICMA 91444 and AUBI 15236 expressed significant positive GCA effects for fodder yield per plant. The present results as in accordance to the report of Mangra et al., (2015).

\section{Specific combining ability (SCA) effects}

Specific combining ability effects estimated for different characters are presented in Table 3.

\section{Days to 50 per cent flowering}

Among thirty two hybrids, fifteen displayed negative SCA effects. Among those hybrids observed in significant higher SCA effects in desired direction were ICMA 91444 x AUBI 15157 in desirable negative direction. Sahane et al., (1996), Sushir et al., (2005) and Mainassara (2012) in their studies also reported similar results for days $50 \%$ flowering.

\section{Days to maturity}

In desirable direction (nagative) two hybrids, ICMA 98222 x AUBI 15039 (-4.95) and ICMA 91444 x AUBI 15308 (-4.71) exhibited significant negative SCA effects for days to maturity. In case of days to maturity earlier same result was also reported by Mainassara (2012).

\section{Plant height}

Out of thirty two cross combinations, the cross ICMA $98222 \times$ AUBI 15157 (20.43) was the best specific combiner for plant height. Three crosses were having significantly negative SCA effects for this trait. Anilkumar et al., (2013) and Nandaniya et al., (2016) observed good general combiner in the crosses showing high SCA effects for plant height.

\section{Number of effective tillers per plant}

Out of thirty two crosses studied, fifteen crosses exhibited negative SCA effects. The cross viz., ICMA $98222 \times$ AUBI 15615 (0.59) displayed significant positive SCA effects. The results are in accordance with studies of Anilkumar et al., (2013), Khandagale et al., (2014), Patel et al., (2016) for effective tillers per plant.

\section{Earhead length}

Among the crosses, only thirteen crosses exhibited significant negative SCA effects. The combination ICMA 91444 x AUBI 15236 exhibited highest significant positive SCA effects. These finding are in confirmity with the findings of Mangra et al., (2015), Khandagale et al., (2014).

\section{Earhead girth}

Out of thirty two crosses, the cross ICMA $06777 \mathrm{x}$ AUBI 15003 showed highest desirable SCA effect. These results are in agreement with the results obtained by Anilkumar et al., (2013), Patel et al., (2016) and Nandaniya et al., (2016).

\section{0 grains weight}

The best specific combinations were ICMA 00888 x AUBI 15026. Similar type of work is reported by Mangra et al., (2015) in this trait. 
Table.1 Analysis of the variance for different characters in L x T mating design in pearl millet.

\begin{tabular}{|c|c|c|c|c|c|c|c|c|c|c|c|}
\hline Source & D.F. & $\begin{array}{c}\text { Days to } \\
\mathbf{5 0 \%} \\
\text { flowering }\end{array}$ & $\begin{array}{c}\text { Days to } \\
\text { maturity }\end{array}$ & $\begin{array}{c}\text { Plant } \\
\text { height }\end{array}$ & $\begin{array}{c}\text { No. of } \\
\text { effective } \\
\text { tillers/ }\end{array}$ & $\begin{array}{c}\text { Ear } \\
\text { head } \\
\text { length }\end{array}$ & $\begin{array}{c}\text { Ear } \\
\text { head } \\
\text { girth }\end{array}$ & $\begin{array}{c}\text { Downey } \\
\text { Mildew }\end{array}$ & $\begin{array}{c}\text { 1000 } \\
\text { grain } \\
\text { weight }\end{array}$ & $\begin{array}{c}\text { Grain } \\
\text { yield } \\
\text { /Plant }\end{array}$ & $\begin{array}{c}\text { Fodder } \\
\text { yield } \\
\text { /plant }\end{array}$ \\
\hline Replications & 1 & 0.73 & 1.92 & 1.28 & 0.0028 & 4.28 & 0.14564 & 00 & 0.29 & 0.34 & $\mathbf{3 . 0 8}$ \\
\hline Treatments & 43 & $8.88^{* *}$ & $26.74 * *$ & $370.55^{* *}$ & $0.45^{* *}$ & $27.75^{* *}$ & $0.37 * *$ & 00 & $14.22^{* *}$ & $123.48 * *$ & $\mathbf{1 6 6 . 2 1} * *$ \\
\hline Error & $\mathbf{4 3}$ & $\mathbf{1 . 4 4}$ & $\mathbf{2 . 3 3}$ & $\mathbf{9 1 . 9 0}$ & $\mathbf{0 . 2 3}$ & $\mathbf{1 4 . 5 2}$ & $\mathbf{0 . 2 0}$ & $\mathbf{0 0}$ & $\mathbf{7 . 7 7}$ & $\mathbf{6 4 . 2 4}$ & $\mathbf{8 9 . 0 5}$ \\
\hline
\end{tabular}

*, ** denote significant at $5 \%$ and $1 \%$ levels, respectively.

Table.2 The parents showing good general combining ability for two or more different traits in pearl millet.

\begin{tabular}{|c|c|c|c|}
\hline Sr. No & Name of the parent & $\begin{array}{l}\text { No. of } \\
\text { Traits }\end{array}$ & Name of the characters \\
\hline 1 & ICMA 98222 & 4 & Days to $50 \%$ flowering, days to maturity, plant height, 1000 grains weight. \\
\hline 2 & ICMA 06777 & 4 & Plant height, no. of effective tillers, earhead length, grain yield. \\
\hline 3 & ICMA 00888 & 3 & No. of effective tillers, earhead length, fodder yield. \\
\hline 4 & ICMA 91444 & 2 & Days to $50 \%$ flowering, fodder yield. \\
\hline 5 & AUBI 15003 & 6 & $\begin{array}{c}\text { Days to maturity, plant height, earhead girth, } 1000 \text { grains weight, grain yield } \\
\text { and fodder yield. }\end{array}$ \\
\hline 6 & AUBI 15236 & 4 & Plant height, no. of effective tillers, earhead length and fodder yield. \\
\hline 7 & AUBI 15308 & 4 & Days to $50 \%$ flowering, plant height, earhead girth and 1000 grains weight. \\
\hline 8 & AUBI 15026 & 4 & Days to maturity, earhead girth, 1000 grains weight and grain yield. \\
\hline 9 & AUBI 15051 & 3 & Days to $50 \%$ flowering, no. of effective tillers, earhead length. \\
\hline
\end{tabular}


Table.3 The hybrids showing best specific combining ability for different characters.

\begin{tabular}{|c|c|c|}
\hline Sr.No. & Name of the character & Best specific combinations \\
\hline $\mathbf{1}$ & Days to $50 \%$ flowering & ICMA 91444 x AUBI 15157 \\
\hline $\mathbf{2}$ & Days to maturity & ICMA 91444 x AUBI 15236 \\
\hline $\mathbf{3}$ & Plant Height & ICMA 9822 x AUBI 15157 \\
\hline $\mathbf{5}$ & No. effective tillers/plant & ICMA 9822 x AUBI 15615 \\
\hline $\mathbf{6}$ & Ear head length & ICMA 91444 x AUBI 15236 \\
\hline $\mathbf{7}$ & Ear head girth & ICMA 06777 x AUBI 15003 \\
\hline $\mathbf{8}$ & 1000 grains weight & ICMA 00888 x AUBI 15026 \\
\hline $\mathbf{9}$ & Grain yield/plant & ICMA 91444 x AUBI 15157 \\
\hline $\mathbf{1 0}$ & Fodder yield/plant & ICMA 9822 AUBI 15308 \\
\hline
\end{tabular}

Fig.1 Ear head with matured pollen grains.

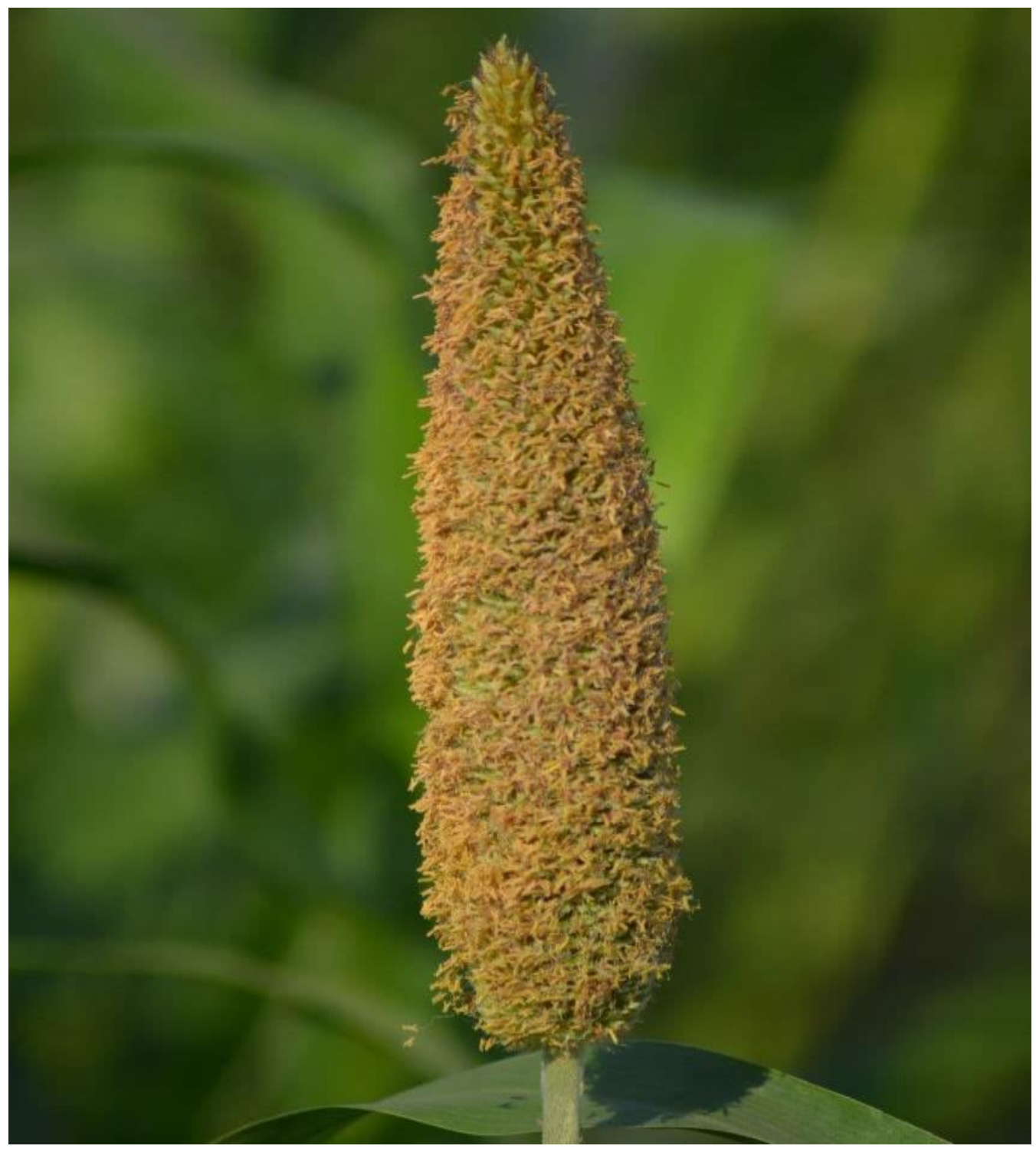


Fig.2 Hybridization techniques in Pearl millet

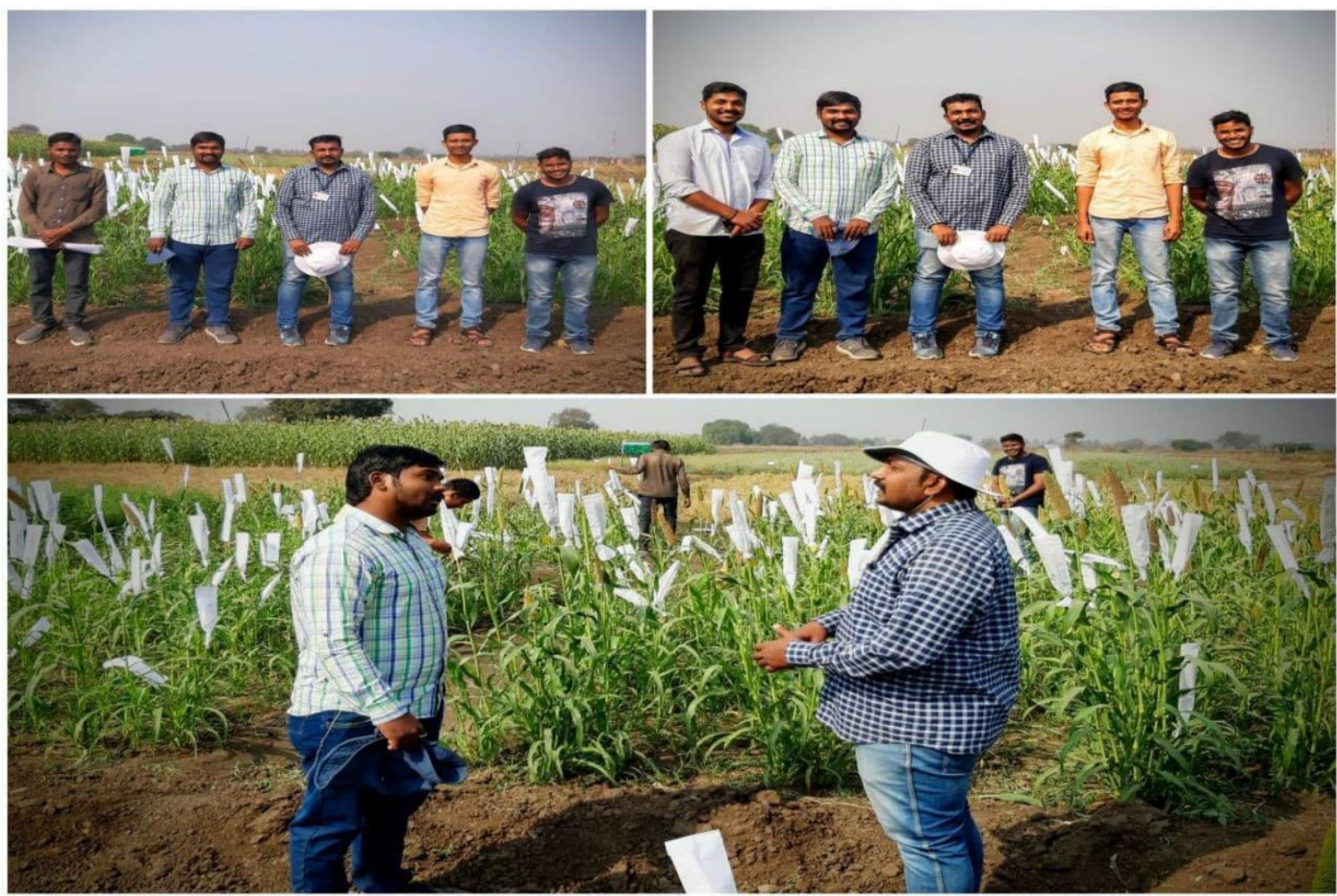

\section{Grain yield per plant}

Amongst the crosses, seventeen cross combination recorded negative SCA effects. The cross ICMA 91444 x AUBI 15157 recorded highest significant positive SCA effect followed by ICMA 91444 x AUBI 15051 for grain yield per plant. These results are in conformity of those results reported by Pethani et al., (2004), Vagadiya et al., (2010).

The relationship between GCA and SCA effects revealed that, significant and desirable SCA effects can occur in any group of parents. These results are in accordance with these obtained by Navale et al., (1991). The occurrence of high SCA effects in good $x$ good group might be due to additiveness of high combining loci and no mutual cancelation of gene effects between high general combinig loci. On the other hand high SCA effects in good $\mathrm{x}$ average or average $\mathrm{x}$ good, average $\mathrm{x}$ poor or poor $\mathrm{x}$ average, poor $x$ poor group might be due to complementation of low, good and poor or average combinig loci. Pethani and Kapoor (1984), Navale (1991) and Mangra et al., (2015) reported presence of at least one good or average general combiner for high SCA effects in most of the traits but poor $\mathrm{x}$ poor combiners also yielded some crosses with high SCA effects.

\section{Fodder yield per plant}

The fifteen hybrids showed significant positive SCA effects for fodder yield per plant. Among ICMA 98222 x AUBI 15308 showed highest significant SCA effects in positive direction for fodder yield per plant is also reported by Navale (1991).

\section{Acknowledgement}

Authors thank to Dr. A. B. Bagade, Assistant Professor (Breeding), National Agricultural Research Project, Paithan Road, Aurangabad for his inspiring guidance, keen interest, his activeness and sharpness. 


\section{References}

Arunachalam V (1974). The fallacy behind the use of a modified line $\mathrm{x}$ tester design. Indian J.Genet. 34: 280.

Anilkumar, I. S. Yadav, and Arya, R. K. (2013). Combining ability and heterosis for some yield traits and protein content in pearl millet. Forage Res., 39 (3):105-113.

Athwal, D. S. (1965). Hybrid Bajara 1 marks a new era. Indian Farming, 15:6-7.

Burton, G. W. (1958). Cytoplasmic male sterility in pearl millet (Pennisetum glaucum (L.) R.Br.). Agron. J., 50: 230.

Harinarayana, G. (1980). Genetic basis for breeding pearl millet populations. "In Trends in Genetical Research on Pennisetum" Ed. V. P. Gupta and J. L. Minocha. P. A. U., Ludhiana. pp. 25-34.

Karad, S. R. and. Harer P. N. (2005). Line x tester analysis in pearl millet. J. Maharashtra Agric. Uni. 30:180-183.

Kempthorne, O. (1957). An introduction to genetic statistics. John Wiley and Sons. Inc. New York. pp. 458-471.

Khandagale, S. G., Sharma, V., Lone, R. P., Khandagale, V. G. and Kumara Swamy, R. V. (2014). Combining ability analysis and gene action in pearl millet [Pennisetum Glaucum (L.) R. Br.]. Electronic J. Plant Breeding, 5 (3): 445-450.

Mainassara, H. (2012). Heterosis and combining ability for grain yield and other agronomic traits in pearl millet (Pennisetum americanum (L.) Leeke). http://hdl.handle.net/123456789/3114.

Mangra, K. S., Dobariya. K. L, Sapovadiya M. H. and Vavdiya. P. A. (2015). Combining ability and gene action for grain yield and its component traits in pearl millet.

Nandaniya K. U., Mungra K. D., and Sorathiya J. S. (2016). Assessment of combining ability for yield and micronutrients in pearl millet. Electronic J. Plant Breeding, 7 (4): 10841088.

Navale, P. A., Kanade B. C., Sarawate C. D. and G. Harinarayana. (1991). Combining ability of newly developed male sterile lines and restorers in pearl millet. J. Maharashtra agric. Univ., 16(1): 17-19.

Patel B. C., Patel M. P. and Patel J. A. (2016). Combining ability studies for grain yield and it's components in pearl millet [(Pennisetum glaucum) (L.) R. Br.]. Electronic J. Plant Breeding. 7 (3): 595-601.

Pethani, K. V. and Kapoor R. L. (1984). Combining ability and its interaction with environments for grain yield in pearl millet. Indian J. agric. Res., 24(1): 11-18.

Pethani, K. V., Atara S. D., and Monpara, B. A. (2004). Heterosis and combing ability for plant and seed characters in pearl millet. National J. Pl. Improv., 6 (2): 115-118.

Sahane, D. V., Navale P. A. and G. Harinarayana. (1996). Combining ability of new male steriles of pearl millet. J. Maharashtra agric. Univ., 20(1): 141- 142.

Shelke, G. V. and Chavan. A. M. (2007). Improvement of agronomically desirable genotypes for down mildew disease resistance in pearl millet [Pennisetum glaucum (L.) R. Br.] by recombination breeding. Journal of Ecobiotechnology 2(1):16-20.

Sushir, K. V., Navale P. A., Patil, H. E.and Gosavi, U. S. (2005). Combining ability for yield components in pearl millet (Pennisetum glaucum (L.) R. Br.). J. Soils and Crops. 15:80-83.

Vagadiya, K. J., Dhedhi. K. K., Jhoshi, H. J., and Vekariya, H. B. (2010). Studies on heterosis in pearl millet (Pennisetum glaucum (L) R. Br.). Agric. Sci. Digest, 30(3): 179-201.

\section{How to cite this article:}

Madane, A. A., A. L. Suradkar, S. B. Pawar and Bagade, A. B. 2021. Combining Ability in Pearl Millet for Yield and Yield Attributing Characters. Int.J.Curr.Microbiol.App.Sci. 10(09): 246-253. doi: https://doi.org/10.20546/ijcmas.2021.1009.028 